\title{
EFFECT OF SALICYLLC ACID FOLIAR APPLICATION ON PHYTOCHEMICAL COMPOSITION, ANTIOXIDANT AND ANTIMICROBIAL ACTIVITY OF SILYBUM MARIANUM
}
Z. Mahmoudi Rad ${ }^{1}$
H. Nourafcan ${ }^{1 *}$ N. Mohebalipour ${ }^{1}$
A. Assadi ${ }^{1}$
S. Jamshidi ${ }^{1}$
Researcher
Assist. Prof.
Assist. Prof.
Assist. Prof. Assist. Prof.

${ }^{1}$ Dept. Hortic. Facu. Agric and Natural Sci. Islamic Azad University Miyaneh Branch, Iran

*Corresponding Author Email Address: nourafcan@m-iau.ac.ir

\section{ABSTRACT}

Silybum marianum (L.), is an important herbal medicine. Silymarin, the active component obtained from its edible seeds, is known for its antioxidant and antimicrobial activity. This research was aimed to study the effect of foliar application of salicylic acid (SA) at four concentrations of $1250,2500,5000$ and $10000 \mu \mathrm{mol} \mathrm{I}^{-1}$ on the improvement of phytochemical composition, antioxidant and antimicrobial activity. Significant increase was found in the content of silibinin, silybin A and silybin B in plants treated with increasing concentrations of salicylic acid. The antioxidant activity was improved with increasing the SA concentration reaching the highest amount under $5000 \mu \mathrm{mol} \mathrm{I}^{-1} \mathrm{SA}$ treatment $(\mathrm{p}<0.05)$. Irrespective to the bacterial strain, an increasing pattern in the amount of antibacterial activity was found by increasing SA concentration. The study suggest that treatments with medium doses of SA could be a promising way to improve the health beneficial flavonolignans compounds of Silybum marianum resulting in a higher antioxidant and antimicrobial activity. Nevertheless, it should be considered that the responses to SA are highly concentration dependent and application of higher concentrations can have an adverse effect by triggering a hyper sensitive cell death pathway.

Key words: antioxidant, SA. concentration, growth regulator, milk thistle, silymarin

تأثير الرش بحامض السالسليك في التركيب الكيميائي والفعلية المايكرويبة زفعالية مضادات الاكسدة لنبات الخرفيش

\section{SILYBUM MARIANUM}

$$
\text { زهاء محمد } \quad \text { باحث }
$$

لمستخلص تهرف الدراسة التحري عن تأثير رش حامض السالسليك باريعة تراكيز (1250 , 2500 , 5000 , مايكرمول لتر -1 ) في تحسين التركيب الكيميائي للنبات والفعالية الضد ميكرويية ومضادات الاكسدة ـ أظهرت النتائج حصول زيادة معنوية في محتوى تركي النبات من سليبينين , سليفباين أو سليباين ب للنباتات المعاملة بتراكيز من السالسليك و لغاية التركيز 5000 مايكرومول لتر

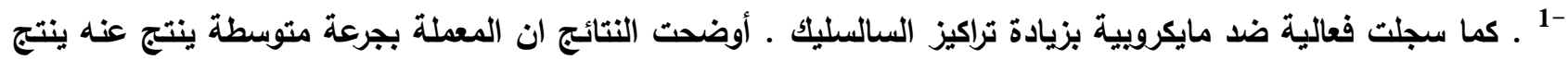

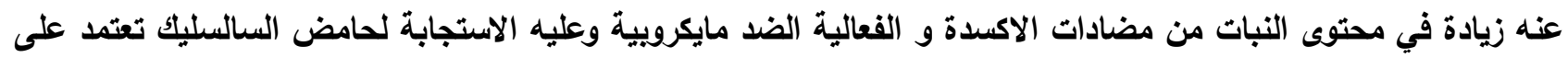

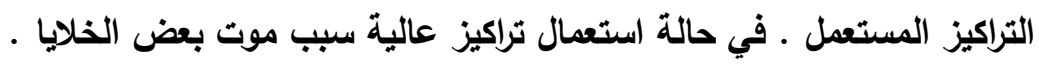
كلمات مفتاحية: مايكروب، سليبيسين، سليفباين أ، سليفباين ب 


\section{INTRODUCTION}

Silybum marianum (L.), also known as milk thistle, is an important herbal medicine. This plant is native to the Mediterranean basin and is widespread in northwest and south of Iran (23). Historically, milk thistle was grown as a food source. The roots can be eaten; flower receptacle eaten like artichokes; the leaves eaten as a spinach substitute; the stalks eaten like asparagus (27). Seeds of milk thistle have been used from centuries for the treatment of liver diseases (hepatitis, cyrosis and icterus), blood cholesterol and containment of cancer $(15,22)$. The active component obtained from its edible seeds is known as silymarin. It contains $65-85 \%$ flavonolignans like silychristin, isosilychristin, silydianin, silybin $\mathrm{A}$ and $\mathrm{B}$, isosilybin $\mathrm{A}$ and $\mathrm{B}$ and also $20-35 \%$ fatty acids, flavonoids and other polyphenolics (7). Given the important pharmacological effects associated with silymarin, many studies have been conducted on the biological activities of these compounds. The liverprotecting abilities of silymarin are due to the antioxidant and free radical scavenging properties. Silymarin has the ability to scavenge free radicals through increasing the production of glutathione in hepatocytes and the activity of superoxide dismutase in erythrocytes (25). Studies have reported the synergistic activity of silibinin when combined with ampicillin and gentamicin against bacteria that attack the oral cavity (16). However, there are few works that evaluated the antimicrobial capacity of silymarin and silibinin, demonstrating the need to extend the study of their therapeutic use in this regard (6). Given the importance of medicinal plants and their biological compounds, the management practices which help to improve the quality of medicinal plants has been in the center of attention. The induction of signaling pathways through the external application of variety of compounds can promote the biosynthesis of phytochemicals. One of the compound widely used as a signaling molecule to improve the biosynthesis of phytochemicals is salicylic acid (SA) (16, 18). SA is as an endogenous plant growth regulator which controls a large variety of physiological processes (8). It is a regulatory signal that mediates plant's defense mechanisms and their response to abiotic stresses (19). Exogenous application of SA is shown to induce many physiological changes including prevention of ethylene production (14); increases in plant growth factor (20) and antioxidant activity (3). This study, was aimed to investigate the effect of foliar application of SA on the (1) the production of major bioactive components of silymarin including silibinin, silybin A and silybin B (2) the amount of antioxidant activity and (3) the degree of antibacterial activity.

\section{MATERIALS AND METHODS}

\section{Growing plants and applying treatments}

The experiments were conducted in the research center of Islamic Azad University Miyaneh Branch, Miyaneh, Iran in 2017. The seeds were obtained from Medicinal Plants Research Center (Ardabil) and grown in small pots filled with vermiculite by $2 \mathrm{~kg}$ soil. When the seedling were $15-20 \mathrm{~cm}$ high and had 2 real leaves, they were transplanted into bigger pots by $4 \mathrm{~kg}$ soils. The pots were irrigated every ten days according to needs of plants. The treatments started 30 days after transferring to the main pots. Treatments were established in a completely randomized experimental design using 15 plants per treatment with three replicates. Treatments consisted of Salicylic acid (SA-2 hydroxybenzoic acid, Merck Millipore Corporation, Germany) foliar application at four concentrations of 1250, 2500, 5000 and $10000 \mu \mathrm{mol} 1^{-1}$. The solutions were applied to the plants every 10 days by spraying using a hand-held sprayer during the whole cultivation period (from vegetative to reproductive phase). In order to avoid interferences with different solution levels, the same amount of distilled water was sprayed to the control plants at a given time.

\section{Extraction procedure}

Silybum marianum seeds were grounded into fine powder using an electric grinder. In order to extract silymarin, five gram of finely powdered samples were weighed and extracted with $250 \mathrm{ml}$ ethanol for $8 \mathrm{~h}$ in a Soxhlet apparatus (Sigma-Aldrich). The extract was allowed to evaporate at room temperature for a period of time till it reached the one third volume of the original extract. Then it was preserved at $4^{\circ} \mathrm{C}$ in vials (1).

\section{Quantification of compounds by HPLC}


The chromatographic analysis was carried out using a Knauer K2600A liquid chromatograph (Germany) equipped with a C18 column (150 $\times 4.6 \mathrm{~mm}$ ) packed with $5 \mu \mathrm{m}$ diameter particles. The mobile phase was a mixture of $85 \%$ phosphoric acid, methanol, and water $\left(1: 46: 64, \mathrm{v} \mathrm{v}^{-1}\right) .10$ micro liter of standards and the samples was injected into the HPLC system at $40{ }^{\circ} \mathrm{C}$ and UV detection. The flow rate was $1 \mathrm{ml} \mathrm{min}^{-1}$ and the wavelength was $288 \mathrm{~nm}$. The identification of silybin (A and B) and silibinin was performed by comparing their retention time and UV absorption spectrum with those of the commercial standards (purity $\geq 98 \%$ grade HPLC, Sigma Aldrich, Germany) (11).

\section{Antioxidant activity}

The antioxidant activity was analyzed using 2,2-diphenyl-1-picrylhydrazyl

(DPPH)

method. The reaction of DPPH was spectrophotometrically measured for $1800 \mathrm{~s}$ at $517 \mathrm{~nm}$ on a CamSpec M501 spectrophotometer. Different volumes of extract $(150-350 \mu \mathrm{l})$ were added to $3 \mathrm{ml}$ of absolute methanol, The diluted extracts were then mixed with $1 \mathrm{ml}$ DPPH ethanolic solution in $96 \%$ ethanol, the decrease of the absorbance at $517 \mathrm{~nm}$ was measured after 30 minutes of storage at room temperature in the dark. The same procedure was applied for the hydroxytoluene butylate (BHT) as a positive control. The antiradical activity was expressed as IC50 $\left.(\mu \mathrm{g} \mathrm{ml})^{-1}\right)$, the concentration of the extracts which caused 50\% inhibitory activity. A lower IC50 value corresponds to a higher antioxidant activity of extracts. The ability to scavenge the DPPH radical was calculated using the following equation:

$\mathrm{DPPH}$ scavenging effect $(\%)=(\mathrm{A} 0-$ A1)/A $0 \times 100$

where A0 is the absorbance of the control at $30 \mathrm{~min}$ and A1 is the absorbance of the sample at $30 \mathrm{~min}$ (2).

\section{Antibacterial activity}

Antibacterial activity of Silybum marianum extracts was determined against eight bacterial strains, Staphylococcus aureus (PTCC 1431), Bacillus cereus (PTCC 1015), Salmonella enterica (PTCC 1787), Proteus mirabilis (PTCC 1776), Klebsiella pneumonia (PTCC 1053), Shigella dysenteria (PTCC 1188), Pseudomonas aeruginosa (PTCC 1074) and
Escherichia coli (PTCC 1399) using the disc diffusion method. A single colony of each bacterial strain was inoculated from a streak plate into $10 \mathrm{ml}$ Mueller Hinton Broth (MHB) medium containing tubes. These tubes were incubated at $37^{\circ} \mathrm{C}$ and a speed of $200 \mathrm{rpm}$ for 16-18 hours as a primary culture. $100 \mu \mathrm{l}$ of primary culture was inoculated into $10 \mathrm{ml}$ MHB media. The tubes were incubated at 37 ${ }^{\circ} \mathrm{C}$ and a speed of $200 \mathrm{rpm}$ till the absorbance reached 0.3 at $600 \mathrm{~nm}$. Then $25 \mathrm{ml}$ agar was poured into the plates slowly, left to solidify and put in the incubator for 24 hours to see for any signs of growth. The next day the plates were clear and ready for inoculation with the bacteria. After inoculating with the bacteria, a sterile $5 \mathrm{~mm}$ paper disc was socked in the crude extract of Silybum marianum and then placed over the surface of the inoculated nutrient agar in antibacterial assay. All plates were incubated at $37^{\circ} \mathrm{C}$ overnight. After incubation, the petri dishes were observed for zone of inhibition. The diameter of zone was measured for recording the clear zone compared with the Di methyl sulfoxide (DMSO) as a control. Experiments were performed in triplicate and mean inhibitory zone was calculated. The standard antibiotics, ampicillin and gentamicin, were used for comparison with the Silybum marianum extracts (4). The minimal inhibitory concentration (MIC) and minimal bactericidal concentration (MBC) of extracts was determined using the microdilution assay. A volume of $1 \mathrm{ml} \mathrm{MHB}$ medium was added to each tube and $1 \mathrm{ml}$ of the extract was used to do a twofold serial dilution giving concentrations of 5 to $0.00781 \mathrm{mg} \mathrm{ml}^{-1}$. Next, $100 \mu \mathrm{l}$ of the bacterial suspension was added to all tubes except the negative control or blank. The negative control contained $1 \mathrm{ml}$ of MHB medium and $1 \mathrm{ml}$ of the extract. Meanwhile, the positive control contained the bacterial suspension MHB, medium and DMSO. The tubes were placed in an incubator for $24 \mathrm{~h}$ at $37{ }^{\circ} \mathrm{C}$. MIC was defined as the lowest concentration at which no bacterial growth (turbidity) was observed. Next, $100 \mu \mathrm{l}$ of tubes with no sign of bacterial growth was transferred and evenly spread on the ager plates. Following $24 \mathrm{~h}$ of incubation at $37{ }^{\circ} \mathrm{C}$, the plates were checked for bacterial growth. 
MBC was defined as the lowest concentration of antimicrobial agent that kills of bacteria (4).

\section{Statistical analysis}

Each experiment was performed three times replicates and the results were normalized by calculation of mean values and the standard deviation. Statistical analyses were performed using GraphPad Prism, version 5.02. Differences between treatments were examined using ANOVA (two-way analysis of variance). The means were compared by Bonferroni post test and considered statistically significant when $P<0.05$ (GraphPad Software, Inc., San Diego, CA).

\section{Content of flavonolignans}

Table 1. Silibinin, Silybin A and Silybin B content in plants treated with different salicylic acid concentrations.

\begin{tabular}{|c|c|c|c|}
\hline Treatment* & g Silybin A/100 g DW & g Silybin B/100 g DW & g Silibin/100 g DW \\
\hline No spraying & $1.506 \mathrm{c} \pm 0.006$ & $1.520 \mathrm{c} \pm 0.005$ & $3.026 \mathrm{c} \pm 0.012$ \\
\hline Water spraying & $1.506 \mathrm{c} \pm 0.006$ & $1.533 \mathrm{c} \pm 0.003$ & $3.040 c \pm 0.010$ \\
\hline $\left.1250 \mathrm{SA}(\mu \mathrm{mol} \mathrm{l})^{-1}\right)$ & $1.590 \mathrm{~b} \pm 0.005$ & $1.600 b \pm 0.015$ & $3.190 b \pm 0.020$ \\
\hline $2500 \mathrm{SA}\left(\mu \mathrm{mol} \mathrm{l}^{-1}\right)$ & $1.593 b \pm 0.008$ & $1.620 b \pm 0.005$ & $3.223 b \pm 0.014$ \\
\hline $5000 \mathrm{SA}\left(\mu \mathrm{mol} \mathrm{l} \mathrm{l}^{-1}\right)$ & $1.633 a \pm 0.008$ & $1.653 a \pm 0.008$ & $3.286 a \pm 0.016$ \\
\hline $\left.10000 \mathrm{SA}(\mu \mathrm{mol} \mathrm{l})^{-1}\right)$ & $1.603 b \pm 0.008$ & $1.620 b \pm 0.005$ & $3.213 b \pm 0.013$ \\
\hline
\end{tabular}

*Values with different letters at each column are statistically different $(P<0.05)$.

\section{DW: Dry Weight}

\section{RESULTS AND DISCUSSION}

Antioxidant activity: With the increase in the concentration of SA, the antioxidant activity was improved (Table 2).

The highest amount of antioxidant activity (indicated by the lowest amount of IC50) was
HPLC analysis of silymarin extract revealed a silybin A and silybin B. Significant increase was found in the content of silibinin, silybin A and silybin $\mathrm{B}$ in plants treated with increasing concentrations of salicylic acid. The highest effect was found in plants treated with 5000 $\mu \mathrm{mol} 1^{-1} \mathrm{SA}$, while higher concentrations can have an adverse effect by triggering a hypersensitive cell death pathway (10). In this study also treatment with higher SA concentration $\left(10000 \mu \mathrm{mol} \mathrm{l}^{-1}\right)$ resulted in a decrease in silibinin, silybin A and silybin B content (Table 1). larger concentration of silibinin compared to

Table 2. Antioxidant activity in plants treated with different salicylic acid concentrations and control

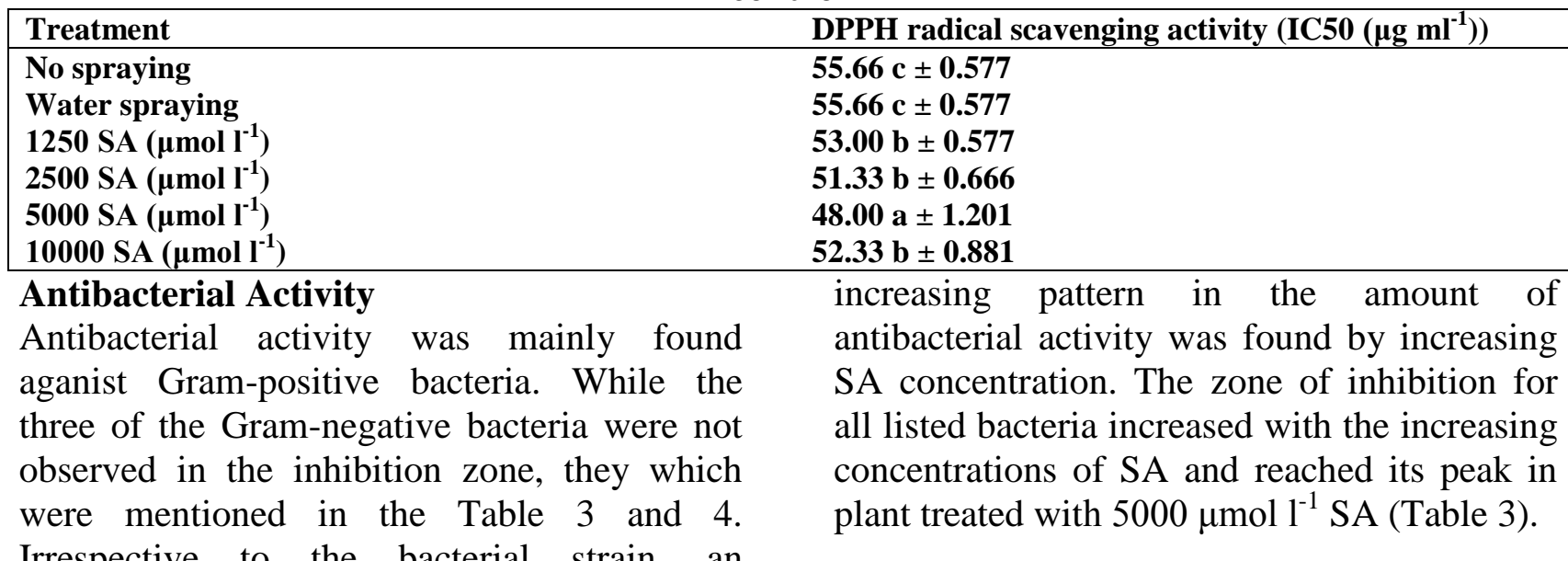

found under $5000 \mu \mathrm{mol} 1^{-1} \mathrm{SA}$ treatment. Further increase in the SA concentration had an adverse effect and resulted in a decrease in antioxidant activity under $10000 \mu \mathrm{mol} \mathrm{l}^{-1} \mathrm{SA}$ treatment. 
Table 3. Inhibition zone diameter of pathogenic strains in plants treated with different salicylic acid concentrations and control

\begin{tabular}{|c|c|c|c|c|c|}
\hline \multirow[t]{2}{*}{ Treatment } & \multicolumn{5}{|c|}{ Inhibition zone diameter (mm) } \\
\hline & $\begin{array}{l}\text { Staphylococcus } \\
\text { aureus }\end{array}$ & Bacillus cereus & $\begin{array}{l}\text { Salmonella } \\
\text { enterica }\end{array}$ & Proteus mirabilis & Escherichia coli \\
\hline No spraying & $8.833 \pm 0.440$ & $8.500 \pm 0.500$ & $8.366 \pm 0.472$ & $8.400 \pm 0.360$ & $8.033 \pm 0.251$ \\
\hline $\begin{array}{l}\text { Water } \\
\text { spraying }\end{array}$ & $8.900 \pm 0.493$ & $8.500 \pm 0.500$ & $8.533 \pm 0.321$ & $8.466 \pm 0.450$ & $8.133 \pm 0.152$ \\
\hline $\begin{array}{l}1250 \\
(\mu \mathrm{mol} \mathrm{l}\end{array}$ & $13.666 \pm 0.3333$ & $13.500 \pm 0.500$ & $13.766 \pm 0.251$ & $14.400 \pm 0.450$ & $13.266 \pm 0.251$ \\
\hline$\underset{\left(\mu \mathrm{mol} \mathrm{I} \mathrm{I}^{-1}\right)}{2500} \mathrm{SA}$ & $15.700 \pm 0.288$ & $15.900 \pm 0.500$ & $15.500 \pm 0.529$ & $14.433 \pm 0.378$ & $13.750 \pm 0.321$ \\
\hline $\begin{array}{l}5000 \\
(\mu \mathrm{mol} \mathrm{l}\end{array}$ & $17.500 \pm 0.288$ & $17.466 \pm 0.953$ & $17.266 \pm 0.458$ & $16.400 \pm 0.360$ & $15.233 \pm 0.100$ \\
\hline$\underset{(\mu \mathrm{mol} \mathrm{I}}{\left.1^{-1}\right)}$ SA & $15.500 \pm 0.288$ & $15.500 \pm 0.450$ & $15.400 \pm 0.461$ & $14.433 \pm 0.360$ & $13.366 \pm 0.251$ \\
\hline DMSO & $\mathbf{0} \pm \mathbf{0 . 0 0}$ & $\mathbf{0} \pm \mathbf{0 . 0 0}$ & $\mathbf{0} \pm \mathbf{0 . 0 0}$ & $\mathbf{0} \pm \mathbf{0 . 0 0}$ & $\mathbf{0} \pm \mathbf{0 . 0 0}$ \\
\hline Methanol & $\mathbf{0} \pm \mathbf{0 . 0 0}$ & $\mathbf{0} \pm \mathbf{0 . 0 0}$ & $\mathbf{0} \pm \mathbf{0 . 0 0}$ & $\mathbf{0} \pm \mathbf{0 . 0 0}$ & $\mathbf{0} \pm \mathbf{0 . 0 0}$ \\
\hline Ampicillin & $\mathbf{3 0 . 3 3 3} \pm \mathbf{0 . 3 3 3}$ & $28.000 \pm 1.000$ & $24.466 \pm 0.450$ & $25.400 \pm 0.360$ & $25.500 \pm 0.500$ \\
\hline Gentamicin & $\mathbf{3 2 . 3 3 3} \pm \mathbf{0 . 3 3 3}$ & $28.833 \pm 0.763$ & $25.533 \pm 0.503$ & $27.566 \pm 0.513$ & $26.733 \pm 0.642$ \\
\hline
\end{tabular}

At this concentration $\left(5000 \mu \mathrm{mol} \mathrm{l}^{-1} \mathrm{SA}\right)$, the inhibition zone was almost two times higher than the control. On the other hand, the MIC and MBC decreased with increasing SA concentration indicating the improvement of antibacterial activity (Table 4).

Table 4. MIC/MBC of pathogenic strains in plants treated with different salicylic acid concentrations and control

\begin{tabular}{|c|c|c|c|c|c|c|c|c|c|c|}
\hline$\underbrace{\mathrm{MIC} / \mathrm{MBC}}_{\left(\mathrm{mgml}^{-1}\right)}$ & $\begin{array}{r}\text { Staph } \\
a\end{array}$ & $\begin{array}{l}\text { occus } \\
\text { s }\end{array}$ & & & $\begin{array}{r}\text { Salm } \\
\text { ent }\end{array}$ & $\begin{array}{l}\text { lella } \\
\text { ica }\end{array}$ & $\begin{array}{l}\text { Pro } \\
\text { mir }\end{array}$ & & $\begin{array}{r}\text { Esch } \\
c\end{array}$ & $\begin{array}{l}\text { richia } \\
\text { li }\end{array}$ \\
\hline & MIC & MBC & MIC & MBC & MIC & MBC & MIC & MBC & MIC & MBC \\
\hline No spraying & 1.25 & 2.50 & 2.50 & 5.00 & 2.50 & 5.00 & 2.50 & 5.00 & 5.00 & - \\
\hline Water spraying & 1.25 & 2.50 & 2.50 & 5.00 & 2.50 & 5.00 & 2.50 & 5.00 & 5.00 & - \\
\hline $1250 \mathrm{SA}\left(\mu \mathrm{mol} \mathrm{I}^{-1}\right)$ & 0.312 & 1.25 & 1.25 & 2.50 & 1.25 & 2.50 & 1.25 & 2.50 & 1.25 & 5.00 \\
\hline $2500 \mathrm{SA}\left(\mu \mathrm{mol} \mathrm{l}^{1}\right)$ & 0.312 & 1.25 & 1.25 & 2.50 & 1.25 & 2.50 & 1.25 & 2.50 & 1.25 & 5.00 \\
\hline $5000 \mathrm{SA}\left(\mu \mathrm{mol} \mathrm{I}^{-1}\right)$ & 0.156 & 0.625 & 0.625 & 1.25 & 0.625 & 1.25 & 0.625 & 2.50 & 1.25 & 5.00 \\
\hline $10000 \mathrm{SA}\left(\mu \mathrm{mol} \mathrm{l} \mathrm{l}^{-1}\right)$ & 0.312 & 1.25 & 1.25 & 2.50 & 1.25 & 2.50 & 1.25 & 5.00 & 2.50 & 5.00 \\
\hline
\end{tabular}

Among the studied bacteria, Staphylococcus aureus was the most sensitive to SA application, indicated by a decrease in MIC from 1.25 in control to 0.156 under $5000 \mu \mathrm{mol}$ $1^{-1}$ SA treatment. Further increase of SA concentration into $10000 \mu \mathrm{mol} \mathrm{l}^{-1}$ resulted in a decrease in the zone of inhibition and an increase in MIC and MBC in all studied strains. This indicates the negative effect of higher SA concentration on the antibacterial activity. The antimicrobial effects of positive control (gentamicin and ampicillin) on Grampositive bacteria were higher than other bacteria with a mean zone of inhibition of 30 $\mathrm{mm}$ in Staphylococcus aureus. The negative control (methanol and DMSO) were ineffective in all strains. This study of silymarin extracts indicated silibinin as the major components, followed by silybin $\mathrm{A}$ and B. The higher concentration of silibinin has been already reported in silymarin extracts (24). We revealed an increasing pattern of silymarin flavonolignans (silybin A, silybin B and silibinin) in response to the foliar SA application reaching the highest concentration at a dose of $5000 \mu \mathrm{mol} \mathrm{1^{-1 }}$. The effect of exogenous SA applications on the accumulation of flavonoids has been shown in several plant species (26). SA application in cell suspensions can induce biochemical stress resulting in an increase in phytochemical compounds (10). It has also been found that $\mathrm{SA}$ induces the production of hydrogen peroxide $\left(\mathrm{H}_{2} \mathrm{O}_{2}\right)$, which stimulates a greater activity of phenylalanine ammonium lyase, responsible for the synthesis of phenolic compounds (12). An increasing pattern in antioxidant activity of silymarin extracts was also observed with increasing SA concentration. Regular applications of salicylic 
acid at different stages of plant growth and fruit development can induce an increase in the antioxidant activity (21). Such influence of SA could be related to the accumulation of phenolic and flavonoids compound which are proved to have antioxidant activity. On the other hand, SA application can have a direct physiological effect on the activity of antioxidant enzymes (13). The effect of seed hormonal priming using SA on the activity of antioxidant enzymes has been recently studied in milk thistle seeds. The increasing concentrations of SA was shown to induce the activity of catalase, peroxidase and polyphenol oxidase (17). The antimicrobial activity of silymarin extracts against a wide range of microorganisms was previously reported (15). Findings have pointed to a synergistic drugmodifying effect when silymarin and silibinin were combined with antibiotics, especially aminoglycosides, against the different bacterial strains evaluated. This study indicated a significant increase in the antimicrobial activity of silymarin extracts with increasing SA concentrations. Such effect could be related to the accumulation of flavonolignans upon SA application. Previous studies have demonstrated a significant inhibitory effect of flavonoids on DNA topoisomerase activity by the formation of complexes that alter enzyme binding (28). The inhibition of this enzyme can therefore interfere with the bacterial synthetic processes (5). This study suggest that treatments with SA could be a promising way to improve the health beneficial flavonolignans compounds of Silybum marianum resulting in a higher antioxidant and antimicrobial activity. Nevertheless, it should be considered that the responses to SA are highly concentration dependent. It is therefore, advisable to use medium doses of SA (up to $5000 \mu \mathrm{mol} \mathrm{l}^{-1}$ ).

\section{REFERENCES}

1-Akinsulier, O. R.; I. E. Aibinu, T.Adenipekun, T. Adelowotan and T. Odugbemi. 2007. In vitro Antimicrobial Activity of crude extracts from plants Bryophyllum pinnatum and Kalanchoe crenata. Afr J Tradit Complement Altern Med. 16;4(3): 338-344.

2-Akowuah, G. A.; Z. Ismail, I. Norhayati and A. Sadikun. 2005. The effects of different extraction solvents of varying polarities on polyphenols of Orthosiphon stamineus and evaluation of the free radical-scavenging activity. Food Chem. 93: 311-317

3-Ananieva, E. A.; K. N. Christov and L. P. Popova. 2004. Exogenous treatment with salicylic acid leads to increased antioxidant capacity in leaves of barley plants exposed to paraquat. J Plant Physiol. 161(3): 319-328

4-Ashraf A. M.; A. Abdulaziz A, A. Khalid S, D. Turki M, Sh. Essam and N, B. Marwah .2018. Antimicrobial activity of some plant extracts against bacterial strains causing food poisoning diseases. Saudi J Biol Sci. 25: 361366

5-Avila, H. P.; E. D. F. A. Smania, F. D. Monache and A. Smania. 2008. Structureactivity relationship of antibacterial chalcones. Bioorg Med Chem. 15;16(22): 9790-9794

6-Bajwa, A.; Sh. Tariq, A. Yuchi, R. Hafeez, A. Arshad, M. Zaman, T. Aqeel and M. N. Mushtaq. 2016. Evaluation of anti-bacterial activity of Silybum marianum against pathogenic and resistant bacteria. European $\mathbf{J}$ Med Plants. 13(4): 1-7

7-Chambers, C. S.; V. Holeckova, L. Petraskova, D. Biedermann, K. Valentova and M. Karkanis, A.; D. Bilalis and A. Efthimiadou. 2011. Cultivation of milk thistle (Silybum marianum L. Gaertn.), a medicinal weed. Ind Crops Prod. 34(1): 825-830

8-Chen, Z.; Z. Zheng, J, Huang. Z. Lai and B. Fan. 2009. Biosynthesis of salicylic acid in plants. Plant Signal Behav. 4(6): 493-496.

9-El-Gaied L. F.; G. A. Abu El-Heba and N. A. El-Sherif . 2013. Effect of growth hormones on some antioxidant parameters and gene expression in tomato. GM Crops Food. 4(1): 67-73.

10-Gao, C.; D. Xing, L. Li and L. Zhang. 2008. Implication of reactive oxygen species and mitochondrial dysfunction in the early stages of plant programmed cell death induced by ultraviolet-C overexposure. Planta. 227(4): 755-767

11-Gunaratna, C. and T. Zhang. 2003. Application of liquid chromatography electrospray ionization-ion trap mass spectrometry to investigate the metabolism of silibin in human liver microsomes. J Chromatogr B Analyt Technol Biomed Life Sci. 794(2): 303-310 
12-Hao, W.; H. Guo, J. Zhang, G. Hu, Y. Yao and J. Dong. 2014. Hydrogen peroxide is involved in salicylic acid-elicited rosmarinic acid production in Salvia miltiorrhiza cell cultures. The 12-Scient World J. http://dx.doi.org/10.1155/2014/843764

13-Huang, R. H.; J. H. liu, Y. M. Lu and R. X. Xia. 2008. Effect of salicylic acid on the antioxidant system in the pulp of 'Cara cara' navel orange (Citrus sinensis L. Osbeck) at different storage temperatures. Postharvest Biol Technol. 47(2): 168-175

14-Khan, W.; B. Prithiviraj and D. L. Smith. 2003. Photosynthetic responses of corn and soybean to foliar application of salicylates. J Plant Phys. 160(5): 485-492

15-Kren, V. and D. Walterova. 2005. Silibin and silymarin. New effects and applications. Biomed. 149(1): 9-41

16-Lee, Y. S.; K. A. Jang and J. D. Cha. 2012. Synergistic antibacterial effect between silibinin and antibiotic in oral bacteria. $\mathbf{J}$ Biomed Biotechnol. http:// dx.doi.org /10.1155 /2012/618081

17-Parmoon, G.; A. Ebadie, S. Jahanbakhsh and S. A. Mossavi. 2017. Effect of salicylic acid on antioxidant enzyms of accelerated aging seeds of milk thistle (Silybum marianum). J Plant Proc Func. 6(20): 57-64

18-Preciado-Rangel, P.; J. J. Reyes-Pérez, S. C. Ramírez-Rodríguez, L. Salas-Pérez, M. Fortis-Hernández, B. Murillo-Amador and E. Troyo-Diéguez. 2019. Foliar aspersion of salicylic acid improves phenolic and flavonoid compounds, and also the fruit yield in cucumber (Cucumis sativus L.). Plants. 8: 44; doi:10.3390/plants8020044

19-Rivas-San Vicente, M. and J. Plasencia. 2011. Salicylic acid beyond defense: its role in plant growth and development. J Experim Bot. 62(10): 3321-3338

20-Saharkhiz, M.; S. Mohammadi, J. Javanmardi and E. Tafazoli. 2011. Salicylic acid changes physio-morphological traits and essential oil content of catnip (Nepeta cataria L.). J Med Spice Plants. 16(2): 75-77

21-Shakirova, F. 2007. Role of Hormonal System in the Manifestation of Growth Promoting and Antistress Action of Salicylic Acid. In: Hayat S, Ahmad A (eds) Salicylic acid: a Plant Hormone. Springer, Dordrecht, The Netherlands pp: 69-89

22-Shaker, E.; H. Mahmoud and S. Mnaa. 2010. Silymarin, the antioxidant component and Silybum marianum extracts prevent liver damage. Food Chemical Toxicol. 48(3): 803806

23-Sidhu, M. and P. Saini. 2012. Silybum marianum: a plant of high medicinal importance a review. World J Pharm Res. 1(2): $72-86$

24-Stancheva, I.; Y. Aegh, M. Geneva, L. Iliev and G. Georgiev. 2008. Regulation of milk thistle (Silybum marianum L.) growth, seed yield and Silymarin content with fertilization and thidiazuron application. Euro J Plant Sci Biotechnol. 2(1): 94-98

25-Surai, P. F. .2015. Silymarin as a natural antioxidant: an overview of the current evidence and perspectives. Antioxidants. 4(1): 204-247

26-Tounekti, T.; I. Hernandez and S. MunneBosch. 2013. Salicylic Acid Biosynthesis and Role in Modulating Terpenoid and Flavonoid Metabolism in Plant Responses to Abiotic Stress. In: Hayat, S.; A. Ahmad and M. Nesser (eds.). Salicylic Acid. Plant Growth and Development, Springer Verlag, Dordrecht, Germany pp: 141-162

27-Tumova, L.; J. Rimakova and J. Tuma. 2006. JandDusek. Silybum marianumin vitro flavonolignan production. Plant, Soil Environ 52(10): 454-8

28-Wang, Q.; H. Wang and M. Xie. 2010. Antibacterial mechanism of soybean isoflavone on Staphylococcus aureus. Arch Microbiol. 192(11): 893-898. 